JIA (Jurnal Ilmiah Akuntansi) • 6 (2), 491-515 • December 2021

\title{
Factors Affecting Earnings Management Islamic Banking Companies at The Indonesia Stock Exchange Publication Year 2013-2019
}

\author{
Firman Syarif ${ }^{*}$, Ahmad Qorib², Saparuddin Siregar², Iskandar \\ Muda $^{1}$ \\ ${ }^{1}$ Universitas Sumatera Utara, Jl. Prof. TM Hanafiah 12, Kampus USU Medan, \\ Sumatera Utara, Indonesia \\ ${ }^{2}$ Universitas Islam Negeri Sumatera Utara, Jl. William Iskandar Ps. V, Medan \\ Estate, Kec. Percut Sei Tuan, Kabupaten Deli Serdang, Sumatera Utara, Indonesia \\ *firman@usu.ac.id
}

\section{CITATION:}

Syarif, F., Qorib, A., Siregar, S., \& Muda, I. (2021). Factors AffectingEarnings Management Islamic Banking Companies at The Indonesia Stock Exchange Publication Year 2013-2019. JIA (Jurnal Ilmiah Akuntansi), 6 (2), 491-515.

\section{ARTICLE HISTORY:}

Received:

July $7^{\text {th }}, 2021$

Revised:

September 19th, 2021

Accepted:

December 28 $8^{\text {th }}, 2021$

DOI: $10.23887 /$ jia.v6i2.36717

\section{Abstract}

This research was conducted on Islamic banking listed on the Indonesia Stock Exchange from 2013-2019 using secondary data. A saturated data analysis is used in this research. The sample is all Sharia banking companies as many as 12 companies. The results show that Institutional Ownership, Managerial Ownership, Individual Ownership, Foreign Ownership, and the Board of Commissioners have an effect on Earnings Management. Meanwhile, State Ownership, Family Ownership, Public Ownership, Public Accountants, Audit Committee, and Board of Directors have no effect on Earnings Management. Simultaneously all independent variables have an effect on Earnings Management. Given their findings, the authors propose that the practical implication of this research is that earnings management does not occur much in Islamic banks listed on the Indonesian Stock Exchange Earnings Management in the study of Islamic Business Ethics is in the form of deliberate fraud or fraud to achieve certain interests and its nature is not for the benefit of the people or society so it is not allowed because it will have an impact on the survival of the company. But interests that are in a precarious condition that endanger the interests of the public or the state, such as a pandemic outbreak, are allowed because the country is experiencing an economic downturn.

Keywords: Audit Committee; Board of Commissioners; Board of Directors; Family Ownership; Foreign Ownership; Individual Ownership; Institutional Ownership; Managerial Ownership; Public Accountant; Public Ownership; State Ownership. 


\section{INTRODUCTION}

One branch of conventional economics and Islamic economics is accounting. The book A Statement of Basic Accounting Theory (ASOBAT) defines that accounting is the process of identifying, measuring and conveying economic information as information material in terms of considering various alternatives in drawing conclusions by users.

Islamic banking is well known in Indonesia, but if we look further, the brand name in Islamic banking is only a name change, but the operational approach still refers to conventional banking. This is due to the fact that its operations still use some employees and capital from conventional banking but for reporting, it uses Islamic accounting standards issued by IAI Syariah. This situation makes it difficult for Islamic banking to operate in terms of capital and daily activities because it is still tied to conventional banks. The marketing of existing Islamic banks is still not able to provide satisfaction to customers, especially Muslims as the majority of potential customers. So that there is an image of an Islamic banking product development approach that is carried out only to promote conventional products.

According to Law No. 21 of 2008 regulates sharia principles and adheres to economic democracy and the principle of prudence. This law provides provisions regarding the types and business activities of Islamic banks and sharia business units, as well as provisions regarding the feasibility of disbursing funds.

In 2017 there was a fraud case at the West Java Syariah Bank that had not been resolved. All of these internal fraud cases involved permanent employees of the company (Finansial, 2019). In addition to internal fraud, there is also a condition of exceeding the maximum limit for disbursement of funds (MLDF) so that this company must report an action plan to improve company compliance in accordance with Bank Indonesia regulations No.: $13 / 5 / \mathrm{PBI} 2011$ concerning the Maximum Limit for Disbursement of Funds for Sharia Rural Banks. In addition, at Bank Syariah Mandiri Tbk (BSM), there was a distribution of fictitious credit financing worth $\mathrm{Rp}$. 102 billion. Potential loss to the state whose shares are 99 percent of BSM's shares are owned by State-Owned Enterprises (BUMN). If BSM makes a loss, then its shareholders must inject additional capital as a backup. This is in accordance with the rules of the Financial Services Authority (OJK), so that capital injections from SOEs to 
their subsidiaries can be categorized as state losses.

The results of calculations by Indonesian Corruption World using various primary data, including audited financial reports, show that the report on sales of agricultural products during 2003-2008 was US\$ 1.06 billion lower than the actual one. As a result, during that time, it is estimated that the state's loss from the lack of revenue from coal production funds (royals) is US\$ 143.29 million (Holief dan Belgiawan, 2018)

In other countries, Earnings Management cases are widely known, including Enron, Merck, World Com and the majority of other companies in the United States. According to Law No. 21 of 2008 concerning Islamic Banking which was issued on July 16, 2008, the development of the national Islamic banking industry is increasingly having an adequate legal basis and will encourage even faster growth. With the impressive development progress, which has reached an average asset growth of more than 65\% per year in the last five years, it is hoped that the role of the Islamic banking industry in supporting the national economy will be increasingly significant (Ermiati et al., 2020).
Financial ratio analysis is a tool to measure financial performance which is also used by Islamic banking and conventional banking which uses a comparison of the previous year's financial statements with the current financial statements. One of the ratios used as a reference for banking is the leverage ratio used, namely CAR. In this study, it is proxied by the Capital Adequacy Ratio (CAR). CAR is a ratio used to measure the adequacy of capital owned by a bank to support assets that contain or generate risk (RWA) such as credit, investment in securities and claims on other banks. While the bank capital used consists of core capital and complementary capital owned by the bank. The relatively high CAR of banking indicates that the banking company has sufficient capital, so that public confidence will increase. However, a CAR that is too high can also indicate an idle fund, which means that there are many idle funds that cannot be utilized by bank management. The bank's financial performance can be seen from the CAR ratio. CAR can evaluate a bank's ability to maintain adequate capital and manage risks that impact the amount of capital (Ermiati et al., 2020).

According to Bank Indonesia Regulation 15/2/PBI/2013, the amount of CAR that must be achieved 
by a bank is at least $8 \%$. This figure is an adjustment to the provisions that apply internationally based on the standards of the Bank for International Settlement (BIS). Profitability ratio is a ratio to assess the company's ability to seek profit in a certain period, in addition to providing a measure of the level of management effectiveness of a company which is indicated by the profit generated from sales or investment income. In addition, the profitability ratio is proxied by Return On Assets (ROA). According to research (Iqbal, 2012), Islamic Bank ROA is lower than conventional banking ROA. However, the ROA value in Islamic banks is still above the ROA value required by Bank Indonesia Circular Letter No. 13/24 DPNP On October 25, 2011, which is above $1.21 \%$, it is stated that the bank has an assessment of the healthy category. So one of the assessments of the company's financial performance is through ROA which can measure the company's performance to generate profits by utilizing existing resources (Azib et al., 2020).

Earnings Management is a profit engineering carried out by directors through internal accountants for certain purposes such as bonuses, avoiding or reducing the amount of tax payable and to convince the banking sector that the company's finances are still in good condition. Earnings Management practices or lying in stating the amount of profit according to Islamic teachings is a practice that is contrary to Islamic ethical values and moral values. Such fraudulent behavior should be eliminated and any practice of manipulating financial statements should be limited.

Mersni \& Ben Othman (2016) show the effectiveness of the work of the audit committee in supervising and controlling management so as to reduce earnings management behavior. Ramachandran et al. (2015) which states that the board of commissioners with a total of greatly improve earnings management behavior. Kolsi \& Grassa (2017) who obtained the results that the proportion independent commissioners have a negative effect on earnings management. As far as researchers know, only a few have been interested in examining the effect of corporate governance on Earnings Management in Islamic banks. As far as researchers know, only a few have been interested in examining the effect of corporate governance on Earnings Management in Islamic banks. This study focuses on the effect of corporate governance mechanisms on the reporting of Loan Loss Provisions 
(PKP) at Islamic banks listed on the Indonesia Stock Exchange (IDX) for the 2013-2019 period. In this regard, reporting of loan loss provisions (PKP) for Islamic banks in Indonesia. The benefit of this research is to add to the literature on governance of Islamic Banks in Indonesia, to add to the repertoire of knowledge about the effect of corporate governance on Earnings Management in Islamic Banks, useful for the compilers of Islamic Financial Accounting Standards, regulators and shareholders. Standard setters and regulators will be able to provide good Financial Accounting Standards regarding Provision for Loan Loss at Islamic Banks in Indonesia and the world, provide additional knowledge about the importance of additional disclosure of banking corporate governance so that managers' discretionary behavior can be reduced so as to prevent Earnings from occurring. Management, helps shareholders to assess the manager's risk when doing discretionary and is expected to find a way out how to prevent managers from doing this opportunistic behavior. Corporate governance mechanism will be able to prevent the emergence of earnings management. Xie.et.al (2001) found that earnings management will be reduced in companies whose directors the purpose of this study is to examine the effect of corporate governance mechanisms on the include independent directors from outside parties and directors who have corporate experience.

\section{Literature Review}

Agency Theory

Agency theory is a theory that arises because of a conflict of interest between the agent and the principal (Panda \& Leepsa, 2017).

\section{Information Asymmetry Theory}

Information asymmetry is a condition in which managers have access to information on company prospects that is not owned by outsiders. Agency theory implies the existence of information asymmetry between managers (agents) and owners (principals).

\section{Stewardship Theory}

Stewardship theory is a theory that describes a situation where managers do not have motivation for individual interests but are more directed to the interests of the organization. Stewardship theory is harmonization between capital owners (principles) and capital managers (stewards) in achieving common goals, but it implicitly reflects how accounting builds a construct of 
leadership patterns and communication relationships between shareholders and management, or it can also occur between top management and other management levels. under him in a corporate organization with situational mechanisms that include management philosophy and differences in organizational culture, and leadership in achieving common goals without hindering the interests of each party.

\section{Resource Dependence Theory}

Humans as social beings cannot be separated from interdependence and help each other. Even though they already have superior resources, humans must have advantages and disadvantages, except that Allah SWT is the most perfect substance.

From a resource dependence view, the board of directors acts to coopt external organizations with which the firm is interdependent. Cooptation refers to the inclusion of outside constituents for diffusing external threats and garnering support essential for organizational survival (Michael,2007).

\section{Transaction Cost Theory}

Transaction cost theory is the cost that arises because of an agreement between other parties and the board of directors to raise new costs for certain interests. Chingtah (2016) microeconomics and traditional theory have not placed much emphasis on trading behavior when describing economic activity, and viewed trading behavior as having very limited influence on the functions of the overall market and mostly ignored it. They believed that in the ideals and operations of the market mechanisms, transactions were natural. Extra costs and expenditures were unnecessary when the market was used to perform economic behaviors or gain market related information.

$$
\text { Coase (1937) suggested a }
$$
different perspective. Coase stated that the uncertainty and complexity of the environment increased costs during the trading operations process. The costs of transactions in the market must be considered. Coase held that so-called transactions refer to technology-independent buyers and sellers from a self-interested perspective, establishing a fixed contractual relationship based on conditions that both sides can accept for their desired products or services and completing exchange activities. 


\section{Sharia Banking Governance}

If we apply Sharia regulations in Islamic banks, then we will focus more on ethical values and moral values in the Islamic banking industry compared to non-Islamic banks. Good governance is the basic principles of sharia that apply ethical values and moral values in the Islamic banking industry. Prohibited transaction activities include: all investment and trading activities on goods and services that are forbidden by Allah, usury, fraud, gambling, transactions containing uncertainty, hoarding of goods, monopoly, engineering requests, bribes, Ta'alluq, repurchase by sellers from the buyer, Tallaqi alRukban, prohibits investing in things that are prohibited by religion such as investing in alcohol, investing in illegal drugs and other underhand and illegal transactions. Another basic principle of sharia is the risk of profit or loss sharing which is used as an alternative to banking based on bank interest. All of these are the basic principles that underlie the differences between Islamic banks and conventional banks.

Earnings Management can cause users of financial statements to be inaccurate in predicting the bank's future prospects. Earnings Management can also hinder communication between banks and investors and can also reduce the stability of the financial sector. In fact, if the bank's performance is not good and bank managers cover up this ugliness, then in the future this situation can cause the bank to collapse. A collapsing bank can cause other banks to collapse. Through the snowball effect, all of this can also cause a collapse for the economy as a whole (Lidyah, 2018).

\section{Corporate Governance Mechanism}

Earnings Management is caused by irregular governance and causes an assessment of financial performance or financial statements to deteriorate, causing managers to try to cover up financial statements by conducting earnings management or earnings management (Azim, 2012).

\section{Institutional Ownership}

Most organizations, companies and institutions seek to improve efficiency. They also improve the ability to analyze better information, provide technology and capital and create better thinking outside the corporate governance system. Efficiency can be continuously reduced by controlling the company and has a different goal from profit maximization (Chung\& Zhang, 2011). The first hypothesis, therefore, can be formulated as follows: 
$\mathrm{H}_{1}$ : Institutional ownership has an influence on earning management.

\section{Managerial Ownership}

Ownership can be concentrated or spread among many owners. The level of concentration and composition of ownership determines the distribution of company power between managers and shareholders, which in itself will affect the nature of decision making that affects the development of the company (Adrian, 2012). The existence of a concentration of ownership in the company will make shareholders strong position. This shows that the holder Stockholders have control over management to demand that they report financial statements accurately. Similar to the role of the board of commissioners in carrying out the supervisory function, the composition of the board can influence the parties management in preparing financial reports so that a quality earnings report can be obtained (Boediono, 2005).

Ownership of a manager will determine the policy and decision making on the accounting methods applied to the companies they manage. In other words, a certain percentage of share ownership by management tends to affect earnings management actions. Based on research from (Ferdawati, 2010), it produces that managerial ownership reduces real earnings management. Based on the research of (Pujiningsih, 2011), results that the ownership structure has a negative effect to earnings management.

So, it can be concluded that when a company has concentration of managerial ownership will also determine the policies and decisionmaking that are applied, so that expected to influence the practice of real earnings management. Based on the theory of managerial ownership structure and previous research, the hypothesis can be formulated as follows:

$\begin{aligned} \mathrm{H}_{2}: & \text { Managerial ownership has an } \\ & \text { influence on earning } \\ & \text { management. }\end{aligned}$

\section{Individual Ownership}

Individual ownership is share ownership by individual investors and majority share ownership of the company's capital of at least $5 \%$. In companies listed on the Stock Exchange, institutional investors are the largest shareholders because they have pension funds and mutual funds. The majority shareholder who is a high level concentration of ownership has great power to monitor management decisions because of the 
authority given by the shareholders as a whole to protect and secure their assets (Jussila et al., 2015).

$\mathrm{H}_{3}$ : Individual ownership has an influence on earning management.

\section{Foreign Ownership}

Foreign Ownership is the number of shares owned by foreign or foreign parties against company shares in Indonesia. Foreign Ownership in a company is a party that is considered concerned with improving Good Corporate Governance (Douma et. al, 2011).

$\begin{array}{rlr}\mathrm{H}_{4} \text { : } & \text { Foreign ownership has an } \\ & \text { influence on earning } \\ & \text { management. }\end{array}$

\section{State of Ownership}

(Deng et al., 2015) stated that state ownership or the private sector will affect the relationship between dividend policy and earnings quality. A minimum of $20 \%$ controlling share ownership for the government opens the opportunity for the government to control company policy (Hartini, 2017). One of them is the dividend policy which is believed to be a factor in earnings quality as mentioned in the principle of positive signals for investors in the signaling theory.

Further, according to (Mousa \& Desoky, 2019), there are several arguments from the study which reveal that companies with state ownership use dividends as an instrument to explore company resources. Research shows that state shareholders prefer cash dividends over stock dividends. Thus, dividend payments made by the company affect the quality of earnings in the company's financial years. The implication is that the power of dividends to influence earnings quality is different in companies with state ownership status (Deng et al., 2015).
$\mathrm{H}_{5}$ : State of ownership has an influence on earning management.

\section{Family Ownership}

Ownership structure is very important in Good Corporate Governance because different ownership structures provide different incentives for managers, including influencing the motivation of Earnings Management (Achmad, 2008).
$\mathrm{H}_{6}$ : Family ownership has an influence on earning management.

\section{Public Ownership}

Public Ownership is the ownership of shares owned by other people who invest capital in the institution. Public Ownership is 
obtained from shares that are widely traded through securities companies in Indonesia. Public Ownership reduces agency conflicts, because Public Ownership can monitor the performance of directors.

$\mathrm{H}_{7}$ : Public ownership has an influence on earning management.

\section{Public Accountant}

The financial statements of each company need to be audited before being published and used by users of these financial statements. An audit of the company's financial statements can be carried out by a Public Accountant or a Public Accountant (KAP).

$\mathrm{H}_{8}$ : Public accountant has an influence on earning management.

\section{Board of Commissioners}

The Board of Commissioners is elected through the Shareholders' Meeting so that the Board of Commissioners functions to oversee the board of directors.

$\mathrm{H}_{9}$ : Board of commissioners $\mathrm{t}$ has an influence on earning management.

\section{Audit Committee}

Characteristics of the Audit Committee The audit committee holds an important role in realizing good corporate governance (GCG) because it is the "eyes" and "ears" of the board of commissioners in order to oversee the running of the company. The existence of an effective audit committee is one aspect assessment in the implementation of GCG (Effendi \& Daljono, 2013). (Pearce \& Zahra, 2007), state that the resource dependence theory argues that the creation of an effective audit committee supervisory function is related to the number of resources owned by the audit committee. The larger the size of the audit committee, the company will have sufficient resources to oversee the company's overall operational activities.

The effective monitoring role of the audit committee can prevent management from presenting low quality financial reports. The characteristics of a good audit committee can affect the effectiveness of the audit committee in carrying out its monitoring role. As a result, management or agents will act more carefully and more transparent in carrying out the company's business activities so that expropriation actions carried out by management on principals carried out through financial statements can be avoided. In Indonesia, the guidelines for the formation of an effective audit committee (KNKG, 2002), explain that 
the members of the audit committee owned by the company consist of at least three people, chaired by an independent commissioner of the company with two independent external persons.

Research on the size of the audit committee has been conducted by (Aryani \& Raharja, 2011), which is to produce the size of the audit committee has no effect on real earningsmanagement. Based on research from (Pujiningsih, 2011), shows the audit committee has a significant effect on earnings management. In addition, (Pratiwi \& Meiranto, 2013), the size of the audit committee has a significant effect on real earnings manipulation.

So, it can be concluded that when a company has characteristics of a good audit committee in accordance with existing regulations and can carry out the monitoring function properly in supervise the company's business activities, then it is expected to reduce the practice of real earnings management. Based on the theory about the characteristics of the audit committee and previous research, the hypothesis can be formulated as follows:

$\begin{aligned} \mathrm{H}_{10} \text { : } & \text { Audit committee has an } \\ & \text { influence on earning } \\ & \text { management. }\end{aligned}$

\section{Board of Directors}

The Board of Directors is considered a pillar of corporate governance, upholding the interests of shareholders and the company. Its role consists of ensuring compliance with accounting principles, preventing the publication of fraudulent financial statements and limiting Earnings Management practices that may occur in the company (Nicholson, Gavin \& Newton, 2010).

$\begin{array}{ccc}\mathrm{H}_{11} \text { : } & \text { Board of directors has an } \\ \text { influence } & \text { on earning } \\ \text { management } & & \end{array}$

\section{METHOD}

\section{Types of research}

This research is included in causal research. This research was conducted on the Indonesia Stock Exchange (IDX), namely www.idx.co.id and islamicmarkets.com.

\section{Operational Definition and \\ Measurement of Research Variables}

The operational definition and measurement of research variables are presented in Table 2.

\section{Population and Research Sample}

The population of the study is all Islamic Banking companies listed on the Indonesia Stock Exchange from 2010 to 2019, they are 12 Islamic Banking. This study is used a 
Table 1. The Review of Previous Study

\begin{tabular}{|c|c|c|c|}
\hline No. & Researcher Name & Research Variable & Research Result \\
\hline 1 . & $\begin{array}{l}\text { Lisna Christiani dan Vina } \\
\text { Herawaty (2019) }\end{array}$ & $\begin{array}{l}\text { Independent Variables: } \\
\text { Managerial Ownership, } \\
\text { Audit Committee. } \\
\begin{array}{l}\text { Dependent Variable: } \\
\text { Earnings Management }\end{array}\end{array}$ & $\begin{array}{l}\text { (1) Managerial Ownership } \\
\text { has an effect on reducing } \\
\text { Earnings Management } \\
\text { (2) The Audit Committee } \\
\text { does not have the effect of } \\
\text { reducing Earnings } \\
\text { Management }\end{array}$ \\
\hline 2. & $\begin{array}{l}\text { Najmi Roid, Yeasy } \\
\text { Darmayanti, Herawati } \\
(2020)\end{array}$ & $\begin{array}{l}\text { Independent Variables: } \\
\text { Family Ownership and } \\
\text { Foreign Ownership. } \\
\text { Dependent Variable: } \\
\text { Earnings Management }\end{array}$ & $\begin{array}{l}\text { (1) Family Ownership has } \\
\text { a significant effect on } \\
\text { Earnings Management } \\
\text { (2) Foreign Ownership } \\
\text { has no significant effect } \\
\text { on Earnings Management }\end{array}$ \\
\hline 3. & $\begin{array}{l}\text { Retna Safriliana dan } \\
\text { Wiwik Rahani (2019) }\end{array}$ & $\begin{array}{l}\text { Independent Variable: } \\
\text { Public Accountant Auditor } \\
\text { Industry Specialization, } \\
\text { Audit Capacity Stress. } \\
\text { Dependent Variable: } \\
\text { Earnings Management }\end{array}$ & $\begin{array}{l}\text { The size of the Public } \\
\text { Accountant which is } \\
\text { proxied based on the } \\
\text { presence or absence of } \\
\text { affiliation with the } \\
\text { International Public } \\
\text { Accountant shows that } \\
\text { the International Affiliated } \\
\text { Public Accountant and the } \\
\text { International Non- } \\
\text { affiliated Public } \\
\text { Accountant have no effect } \\
\text { on Earnings Management } \\
\text { through manipulation of } \\
\text { real activities. }\end{array}$ \\
\hline 4. & Gunawan (2016) & $\begin{array}{l}\text { Independent Variables: } \\
\text { Board of Commissionaires, } \\
\text { Managerial Ownership, } \\
\text { Audit Committee. } \\
\text { Dependent Variable: } \\
\text { Earnings Management }\end{array}$ & $\begin{array}{l}\text { (1) Independent Board of } \\
\text { Commissionaires has no } \\
\text { effect on Earnings } \\
\text { Management } \\
\text { (2) Managerial Ownership } \\
\text { has the effect of reducing } \\
\text { Management Earnings } \\
\text { (3) Audit Committee } \\
\text { proved to have no effect on } \\
\text { Earnings Management }\end{array}$ \\
\hline 5. & $\begin{array}{l}\text { Rini Kumala and Sylvia } \\
\text { Veronica Siregar (2016) }\end{array}$ & $\begin{array}{l}\text { Independent Variables: } \\
\text { Social } \\
\text { Disclosure, }\end{array}$ & $\begin{array}{l}\text { The results of the study } \\
\text { stated that Social } \\
\text { Responsibility had a } \\
\text { negative effect on } \\
\text { Earnings Management, } \\
\text { while Family Ownership } \\
\text { had a positive effect on } \\
\text { Earnings Management. }\end{array}$ \\
\hline
\end{tabular}




\begin{tabular}{|c|c|c|c|}
\hline No. & Researcher Name & Research Variable & Research Result \\
\hline 6. & $\begin{array}{l}\text { Wisnu Arwindo Irawan } \\
\text { (2013) }\end{array}$ & 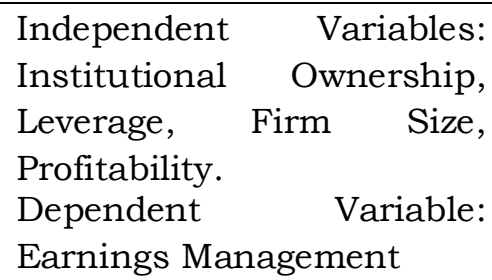 & $\begin{array}{l}\text { Institutional Ownership } \\
\text { has been proven to have a } \\
\text { significant negative effect } \\
\text { on Earnings Management }\end{array}$ \\
\hline 7. & $\begin{array}{l}\text { Yousef Ibrahim Suleiman } \\
\text { Abu Siam, Nur Hidayah } \\
\text { Binti Laili, Khairil Faizal } \\
\text { Bin Khair (2014) }\end{array}$ & $\begin{array}{l}\text { Independent Variable: } \\
\text { Board of Directors. } \\
\text { Dependent Variable: } \\
\text { Earnings Management }\end{array}$ & $\begin{array}{l}\text { The results showed that } \\
\text { the Board of Directors had } \\
\text { a negative effect on } \\
\text { Earnings Management. }\end{array}$ \\
\hline 8. & $\begin{array}{l}\text { Restu Agusti dan Tyas } \\
\text { Pramesti (2008) }\end{array}$ & $\begin{array}{lr}\text { Independent } & \text { Variables: } \\
\text { Information } & \text { Asymmetry, } \\
\text { Firm Size, } & \text { Managerial } \\
\text { Ownership. } & \\
\text { Dependent } & \text { Variable: } \\
\text { Earnings Management }\end{array}$ & $\begin{array}{l}\text { Managerial Ownership has } \\
\text { a positive and significant } \\
\text { effect on Earnings } \\
\text { Management in } \\
\text { manufacturing companies } \\
\text { listed on the Indonesian } \\
\text { stock exchange for the } \\
\text { 2005-2007observation } \\
\text { period }\end{array}$ \\
\hline 9. & Saputra et al (2014) & $\begin{array}{l}\text { Independent variables: } \\
\text { state ownership, Family } \\
\text { Ownership. } \\
\text { Dependent variable: } \\
\text { Earnings Management }\end{array}$ & $\begin{array}{l}\text { Government (state) } \\
\text { ownership has a positive } \\
\text { but not significant impact } \\
\text { on Earnings Management }\end{array}$ \\
\hline 10. & $\begin{array}{l}\text { Yuan Ding, Hua Zhang, } \\
\text { Junxi Zhang (2007) }\end{array}$ & $\begin{array}{lc}\text { Independent } & \text { Variables: } \\
\text { Individual } & \text { Ownership, } \\
\text { State of } & \text { Ownership. } \\
\text { Dependent } & \text { Variable: } \\
\text { Earnings Management }\end{array}$ & $\begin{array}{l}\text { The results of this study } \\
\text { indicate that Individual } \\
\text { ownership has a more } \\
\text { significant positive effect } \\
\text { on Earnings Management } \\
\text { compared to State of } \\
\text { Ownership }\end{array}$ \\
\hline 11. & $\begin{array}{l}\text { Dan Givoly, Carla Hayn, } \\
\text { Sharon P. Katz (2008) }\end{array}$ & $\begin{array}{ll}\text { Independent } & \text { Variable: } \\
\text { Public Ownership } & \\
\text { Dependent } & \text { Variable: } \\
\text { Earnings Quality } & \end{array}$ & $\begin{array}{l}\text { The results of this study } \\
\text { indicate that Public } \\
\text { Ownership has a positive } \\
\text { effect on the practice of } \\
\text { Earnings Management by } \\
\text { managers }\end{array}$ \\
\hline
\end{tabular}

Sources: processed by researchers, 2020

Table 2. Operational Definition and Measurement Scale of Islamic Bank Variables

\begin{tabular}{lll}
\hline \multicolumn{1}{c}{ Variable } & \multicolumn{1}{c}{ Variable Definition } & $\begin{array}{c}\text { Measurement } \\
\text { Scale }\end{array}$ \\
\hline & $\begin{array}{l}\text { Manager's efforts to DAt = TACt/At-1 - NDAt } \\
\text { influence Ratio } \\
\text { information in the }\end{array}$ & \\
Earnings & $\begin{array}{l}\text { financial statements so } \\
\text { Management }(\mathrm{Y})\end{array}$ & $\begin{array}{l} \\
\text { that it is no longer } \\
\text { objective. }\end{array}$ \\
\hline
\end{tabular}




\begin{tabular}{|c|c|c|}
\hline Variable & Variable Definition & $\begin{array}{l}\text { Measurement } \\
\text { Scale }\end{array}$ \\
\hline $\begin{array}{l}\text { Institutional } \\
\text { Ownership } \\
\left(\mathrm{X}_{1}\right)\end{array}$ & $\begin{array}{l}\text { The ownership } \\
\begin{array}{l}\text { of } \\
\text { company shares }\end{array} \text { by ownership/Total shares) } \\
\text { other institutions }\end{array}$ & Ratio \\
\hline $\begin{array}{l}\text { Managerial } \\
\text { Ownership }\left(\mathrm{X}_{2}\right)\end{array}$ & $\begin{array}{l}\text { The level of share (Managerial } \\
\text { ownership by ownership/total } \\
\text { management who is shares) } \\
\text { actively involved in } \times 100 \% \\
\text { decision making }\end{array}$ & Ratio \\
\hline $\begin{array}{l}\text { Individual Ownership } \\
\left(\mathrm{X}_{3}\right)\end{array}$ & $\begin{array}{ll}\text { Minority share } & \text { (Individual } \\
\text { ownership by outsiders } & \text { ownership/total shares) } \times \\
\text { or the public other } & 100 \% \\
\text { than shares owned by } & \\
\text { managers. } & \end{array}$ & Ratio \\
\hline $\begin{array}{l}\text { Foreign Ownership } \\
\left(\mathrm{X}_{4}\right)\end{array}$ & $\begin{array}{ll}\text { Foreign Ownership } & \text { (Foreign } \text { ownership/total } \\
\text { adalah persentase } & \text { shares) } \times 100 \% \\
\text { kepemilikan saham } & \\
\text { perusahaan oleh } & \\
\text { investor asing. } & \\
\end{array}$ & Ratio \\
\hline $\begin{array}{l}\text { State of Ownership } \\
\left(\mathrm{X}_{5}\right)\end{array}$ & $\begin{array}{ll}\begin{array}{l}\text { State of Ownership is } \\
\text { the ownership of }\end{array} & \begin{array}{l}\text { State of ownership/total } \\
\text { shares) } \times 100 \%\end{array} \\
\text { company shares } \\
\text { owned by government. }\end{array}$ & Ratio \\
\hline $\begin{array}{l}\text { Family Ownership } \\
\left(\mathrm{X}_{6}\right)\end{array}$ & $\begin{array}{l}\text { Companies whose (Number of shares } \\
\text { family-owned } \\
\text { owned by the family/ } \\
\text { than } 20 \% \text { of the voting shares) } \times 100 \% \\
\text { rights }\end{array}$ & Ratio \\
\hline $\begin{array}{l}\text { Public Ownership } \\
\left(\mathrm{X}_{7}\right)\end{array}$ & $\begin{array}{l}\text { Share ownership by (Public ownership/total } \\
\text { other people who shares) } \times 100 \% \\
\text { invest capital into the } \\
\text { institution. }\end{array}$ & Ratio \\
\hline $\begin{array}{l}\text { Public Accountant } \\
\left(\mathrm{X}_{8}\right)\end{array}$ & $\begin{array}{l}\text { Public Accountants Public Accountants who } \\
\text { have a role in are part of the Big Four } \\
\text { assessing the quality Public Accountants. } \\
\text { the company's } \\
\text { financial statements } \\
\text { for a period. }\end{array}$ & Nominal \\
\hline $\begin{array}{l}\text { Board of } \\
\text { Commisionairs }\left(\mathrm{X}_{9}\right)\end{array}$ & 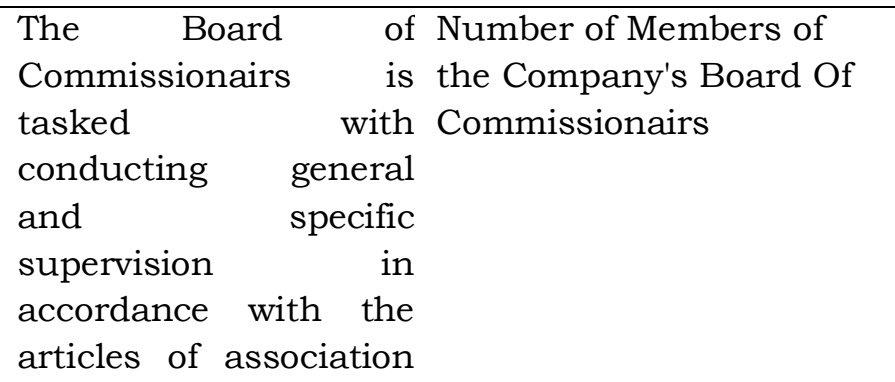 & Nominal \\
\hline
\end{tabular}




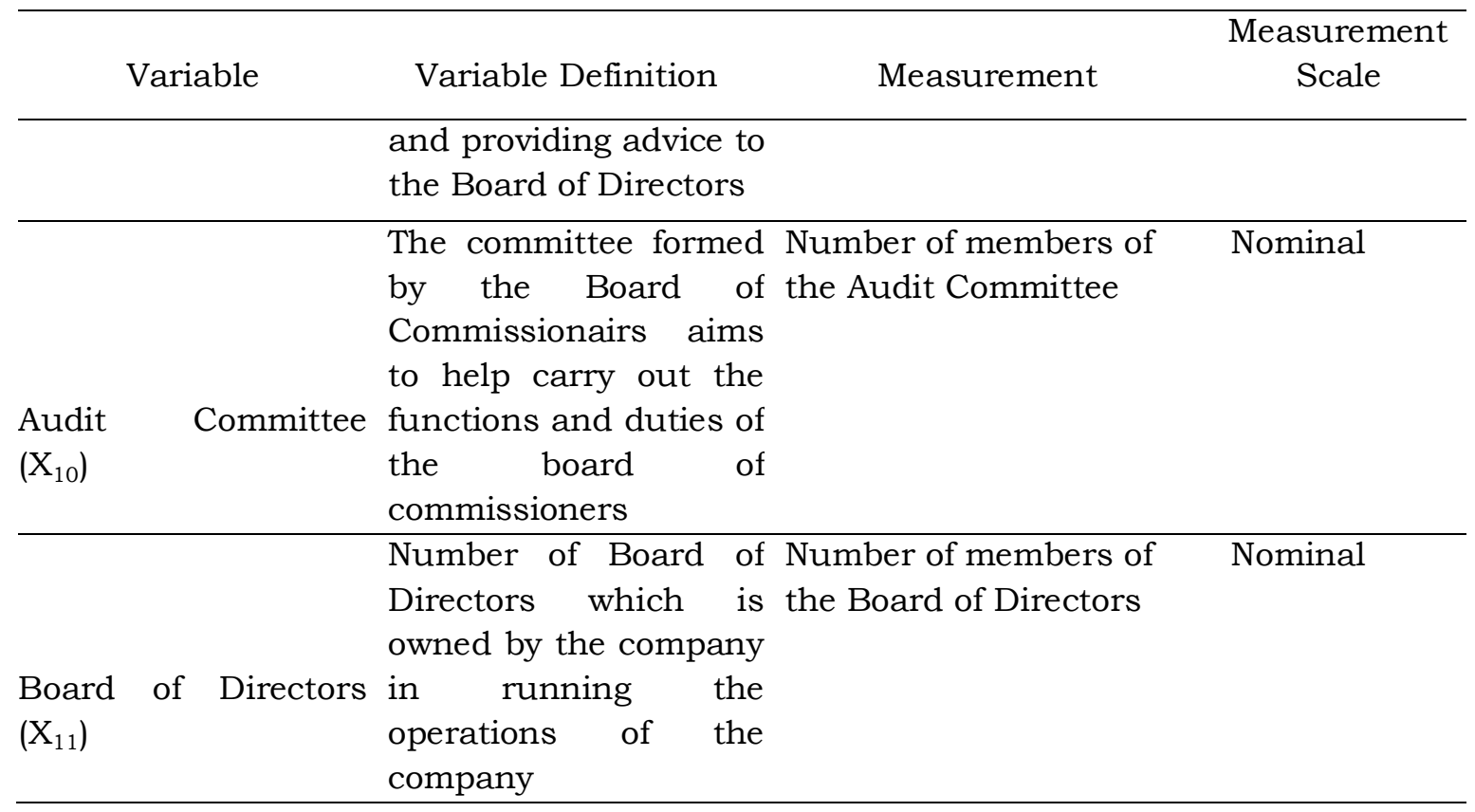

saturated data analysis. So, the sample is all Sharia Banking companies.

\section{Types of Islamic Banking Data}

The type of data used in this study is secondary data or research data obtained indirectly through intermediary media, namely the annual reports of banking companies, both sharia and private sectors that have been audited and published through www.idx.co.id from islamicmarket.com

\section{Data Analysis}

The software program used in this study is Eviews 10. According to (Ghozali, 2018) the regression analysis of Islamic Bank panel data with the panel data regression model developed aims to test the hypotheses that have been formulated in this study:

$$
\begin{aligned}
Y=a+\beta_{1} X_{1}+\beta_{2} X_{2}+\beta_{3} X_{3}+\beta_{4} X_{4}+\beta_{5} X_{5}+\beta_{6} X_{6}+ \\
\beta_{7} X_{7}+\beta_{8} X_{8}+\beta_{9} X_{9}+\beta_{10} X_{10}+ \\
\beta_{11} X_{11}+\mathbf{C}
\end{aligned}
$$

\section{RESULT AND DISCUSSION}

\section{Results}

The descriptive statistical analysis of Islamic Banks is presented in Table 3. The mean, median, maximum and minimum values of Institutional Ownership, Managerial Ownership, Individual Ownership, Foreign Ownership, State of Ownership, Family Ownership, Public Ownership, Board of Commissioners, Public Accountant, Audit Committee and Board of Directors can be seen from the descriptive statistical test on Table 3 and Table 4. 


\section{Precise Panel Data Regression}

Chow test

Chow test is a tool to test the equality of coefficients. This test is performed to determine whether the selected model is Common Effect Model or Fixed Effect Model.

\section{Sharia Bank Chow Test}

The results of the Chow test in this study can be seen in Table 5 .
Based on Table 5 for the results of the Chow test, it is concluded that the probability cross section $\mathrm{F}$ is 0.0000 . This means that $\mathrm{H}_{0}$ is rejected with probability cross section $\mathrm{F}<0.05$ and $\mathrm{H}_{1}$ is accepted. So, in this Chow test, the model chosen is the Common Effect Model.

Table 3. Descriptive Statistics of Islamic Banks

\begin{tabular}{|c|c|c|c|c|c|c|}
\hline & $\begin{array}{c}M N J_{-} L A B A \\
{ }_{-} Y\end{array}$ & $\begin{array}{c}K E P \_I N S T I \\
\text { TUSIONAL } \\
\quad X 1\end{array}$ & $\begin{array}{c}\text { KEP_MAN } \\
\text { AJERIAL_ } \\
\text { X2 }\end{array}$ & $\begin{array}{c}\text { KEP_INDI } \\
\text { VIDUAL_X } \\
3\end{array}$ & $\begin{array}{c}K E P_{-} A S I N G_{-} \\
X 4\end{array}$ & $\begin{array}{c}K E P \_N E G A R \\
A \_X 5\end{array}$ \\
\hline Mean & 2.225 .876 & 1.054 .988 & 4.388 .520 & 1.170 .607 & 5.257 .800 & 1.205 .213 \\
\hline Median & 2.099 .000 & 0.000000 & 3.196 .000 & 0.000000 & 0.000000 & 0.000000 \\
\hline Maximum & 6.881 .000 & 6.241 .700 & 2.226 .300 & 6.241 .700 & 2.673 .300 & 7.605 .000 \\
\hline Minimum & 1.884 .000 & 0.000000 & 0.800000 & 0.000000 & 0.000000 & 0.000000 \\
\hline Std. Dev. & 1.702 .497 & 1.885 .230 & 4.182 .433 & 1.991 .075 & 8.909 .068 & 2.447 .913 \\
\hline Skewness & 0.852267 & 1.355 .415 & 1.712 .302 & 1.180 .907 & 1.155 .307 & 1.568 .480 \\
\hline Kurtosis & 2.878 .039 & 3.158 .736 & 7.051 .468 & 2.586 .433 & 2.487 .253 & 3.585 .279 \\
\hline Jarque-Bera & 9.125 .974 & 2.304 .310 & 8.794 .469 & 1.796 .627 & 1.750 .576 & 3.182 .209 \\
\hline Probability & 0.010431 & 0.000000 & 0.000000 & 0.000126 & 0.000158 & 0.000000 \\
\hline Sum & 16694.07 & 79124.10 & 32913.90 & 87795.50 & 39433.50 & 9.039 .100 \\
\hline $\begin{array}{l}\text { Sum } \\
\text { Dev. }\end{array}$ & 2144886. & $2.63 \mathrm{E}+08$ & 12944633 & $2.93 \mathrm{E}+08$ & 58734906 & 4434284. \\
\hline Observations & 75 & 75 & 75 & 75 & 75 & 75 \\
\hline
\end{tabular}


The Panel Data Regression Equation

\section{Analysis}

The results of data processing shown in Table 6 produce the following panel data equations:

$\mathrm{Y}=205.2252-0.043180\left(\mathrm{X}_{1}\right)-0.124009$

$\left(\mathrm{X}_{2}\right)-0.041960\left(\mathrm{X}_{3}\right)-0.055226\left(\mathrm{X}_{4}\right)-$

$0.223555\left(\mathrm{X}_{5}\right)+0.037592\left(\mathrm{X}_{6}\right)-$

$0.077786 \quad\left(X_{7}\right) \quad--0.039493 \quad\left(X_{8}\right)-$

$$
\begin{aligned}
& 0.314316\left(\mathrm{X}_{9}\right)+0.523433\left(\mathrm{X}_{10}\right)- \\
& 0.020932\left(\mathrm{X}_{11}\right)+\varepsilon
\end{aligned}
$$

The panel data equation above explained as follows: The constant value (C) of 205,2252 indicates a constant value, which means that if all the independent variables, namely Institutional Ownership, Foreign

\begin{tabular}{|c|c|c|c|c|c|c|}
\hline & $\begin{array}{c}K E P \_K E L U \\
A R G A \_X 6\end{array}$ & $\begin{array}{c}\text { KEP_MAS } \\
Y A R A K A T \\
\_X 7\end{array}$ & $K A P_{-} X 8$ & $\begin{array}{c}D E K O M \_D P \\
S \_X 9\end{array}$ & $\begin{array}{c}K_{-} A U D I T_{-} \\
X 10\end{array}$ & $\begin{array}{c}D \_D I R E K S \\
I \_X 11\end{array}$ \\
\hline Mean & 1.532 .267 & 1.175 .027 & 1.729 .160 & 7.994 .800 & 1.216 .800 & 2.210 .517 \\
\hline Median & 0.000000 & 0.000000 & 0.000000 & 0.000000 & 0.000000 & 2.015 .800 \\
\hline Maximum & 9.224 .000 & 7.605 .000 & 2.226 .300 & 6.697 .000 & 1.418 .000 & 6.241 .700 \\
\hline Minimum & 0.000000 & 0.000000 & 0.000000 & 0.000000 & 0.000000 & 3.000 .000 \\
\hline Std. Dev. & 2.466 .146 & 2.436 .944 & 4.304 .600 & 1.543 .557 & 3.213 .668 & 1.603 .105 \\
\hline Skewness & 1.765 .443 & 1.659 .391 & 3.008 .256 & 1.953 .992 & 2.713 .552 & 0.466971 \\
\hline Kurtosis & 5.283 .544 & 3.917 .654 & 1.188 .372 & 6.301 .106 & 9.240 .754 & 2.645 .167 \\
\hline Jarque-Bera & 5.525 .542 & 3.705 .125 & 3.597 .468 & 8.178 .014 & 2.137 .515 & 3.119 .229 \\
\hline Probability & 0.000000 & 0.000000 & 0.000000 & 0.000000 & 0.000000 & 0.210217 \\
\hline Sum & 11492.00 & 8.812 .700 & 12968.70 & 5.996 .100 & 9.126 .000 & 165788.8 \\
\hline Sum Sq. Dev. & 4500588. & 4394634. & 13711892 & 1763101. & 76424.68 & $1.90 \mathrm{E}+08$ \\
\hline Observations & 75 & 75 & 75 & 75 & 75 & 75 \\
\hline
\end{tabular}

Table 4. Descriptive Statistics of Islamic Banks

Sources: processed by researchers, 2020 


\section{Table 5. The Sharia Bank Chow Test Results}

Redundant Fixed Effects Tests

Equation: Untitled

Test cross-section fixed effects

\begin{tabular}{lrrr}
\hline \hline Effects Test & Statistic & d.f. & Prob. \\
\hline \hline Cross-section F & 2.588552 & $(10,44)$ & 0.0146 \\
Cross-section Chi-square & 30.536143 & 10 & 0.0007 \\
\hline \hline
\end{tabular}

Cross-section fixed effects test equation:

Dependent Variable: Y

Method: Panel Least Squares

Date: 01/30/21 Time: 11:19

Sample: 20132019

Periods included: 7

Cross-sections included: 11

Total panel (unbalanced) observations: 66

\begin{tabular}{|c|c|c|c|c|}
\hline Variable & Coefficient & Std. Error & t-Statistic & Prob. \\
\hline $\mathrm{C}$ & 16935.23 & 4043.828 & 4.187921 & 0.0001 \\
\hline $\mathrm{X} 1$ & 3.980290 & 1.757431 & 2.264834 & 0.0276 \\
\hline $\mathrm{X} 2$ & -3.522793 & 4.151360 & -0.848588 & 0.3999 \\
\hline $\mathrm{X} 3$ & 4.367394 & 1.777265 & 2.457367 & 0.0172 \\
\hline $\mathrm{X} 4$ & 8.553792 & 2.624197 & 3.259585 & 0.0019 \\
\hline $\mathrm{X} 5$ & -21.10735 & 8.783784 & -2.402990 & 0.0197 \\
\hline $\mathrm{X} 6$ & 1.851603 & 5.162121 & 0.358690 & 0.7212 \\
\hline $\mathrm{X} 7$ & -0.356292 & 1.011111 & -0.352377 & 0.7259 \\
\hline $\mathrm{x} 8$ & 0.734226 & 0.989028 & 0.742371 & 0.4611 \\
\hline $\mathrm{X} 9$ & 1.725905 & 1.406561 & 1.227039 & 0.2251 \\
\hline $\mathrm{X} 10$ & 45.05762 & 53.22033 & 0.846624 & 0.4009 \\
\hline $\mathrm{X} 11$ & -2.227605 & 1.369816 & -1.626208 & 0.1097 \\
\hline$\overline{\text { R-squared }}$ & 0.871621 & \multicolumn{2}{|l|}{ "Mean dependent var } & 21776.32 \\
\hline Adjusted R-squared & 0.845470 & \multicolumn{2}{|l|}{ S.D. dependent var } & 17636.08 \\
\hline S.E. of regression & 6932.807 & \multicolumn{2}{|l|}{ Akaike info criterion } & 20.68888 \\
\hline Sum squared resid & $2.60 \mathrm{E}+09$ & \multicolumn{2}{|l|}{ Schwarz criterion } & 21.08700 \\
\hline Log likelihood & -670.7331 & \multicolumn{2}{|l|}{ Hannan-Quinn criter. } & 20.84620 \\
\hline F-statistic & 33.32991 & \multicolumn{2}{|l|}{ Durbin-Watson stat } & 1.055891 \\
\hline Prob(F-statistic) & 0.000000 & & & \\
\hline
\end{tabular}

Sources: processed by researchers, 2020 


\section{Table 6. The Results of Islamic Banking Panel Data Regression Analysis}

Dependent Variable: MNJ_LABA_Y_

Method: Least Squares

Date: 01/27/21 Time: 19:43

Sample: 175

Included observations: 75

\begin{tabular}{lrccc}
\hline \hline \multicolumn{1}{c}{ Variable } & Coefficient & Std. Error & t-Statistic & Prob. \\
\hline \hline C & 205.2252 & 42.42581 & 4.837273 & 0.0000 \\
KEP_INSTITUSIONAL_X1_ & -0.043180 & 0.014755 & 2.926381 & 0.0048 \\
KEP_MANAGERIAL_X2_- & -0.124009 & 0.039489 & 3.140366 & 0.0026 \\
KEP_INDIVIDUAL_X3_ & -0.041960 & 0.012747 & 3.291754 & 0.0016 \\
KEP_ASING_X4_ & -0.055226 & 0.027020 & 2.043887 & 0.0452 \\
KEP_NEGARA_X5_ & -0.223555 & 0.132271 & 1.690129 & 0.0959 \\
KEP_KELUARGA_X6_ & 0.037592 & 0.052027 & -0.722551 & 0.4726 \\
KEP_MASYARAKAT_X7_ & -0.077786 & 0.138330 & 0.562323 & 0.5759 \\
KAP_X8_ & -0.039493 & 0.042436 & -0.930656 & 0.3556 \\
DEKOM_DPS_X9_ & -0.314316 & 0.148380 & 2.118318 & 0.0381 \\
K_AUDIT_X10_ & 0.523433 & 0.504414 & 1.037705 & 0.3034 \\
D_DIREKSI_X11_ & -0.020932 & 0.015686 & 1.334494 & 0.1868 \\
\hline \hline R-squared & 0.804261 & Mean dependent var & 222.5876 \\
Adjusted R-squared & 0.770084 & S.D. dependent var & 170.2497 \\
S.E. of regression & 81.63387 & Akaike info criterion & 11.78801 \\
Sum squared resid & 419837.6 & Schwarz criterion & 12.15881 \\
Log likelihood & -430.0505 & Hannan-Quinn criter. & 11.93607 \\
F-statistic & 23.53248 & Durbin-Watson stat & 1.252894 \\
Prob(F-statistic) & 0.000000 & & & \\
\hline \hline
\end{tabular}

Sources: Output Eviews 10.0, processed by researchers, 2020

Ownership, Public Ownership, Public Accountants, Board of Commissionairs, Audit Committee, Board of Directors, are 0 , then the level of the dependent variable (Earnings Management) is 205,2252.
Based on the regression results, the output display in Table 6 above shows the adjusted R-squared value of 0.770084 which means the variation of 11 independent variables, namely Institutional Ownership, Managerial Ownership, Individual 
Ownership, Foreign Ownership, State of Ownership, Family Ownership, Public Ownership, Public Accountants, Board of Commissionairs, Audit Committee and Board of Directors were able to explain the variation of $\mathrm{Y}$ (Earnings Management) variable of $77.00 \%$.

\section{Discussions}

Partial Research Results on Earnings Management $(Y)$

The results of the partial test $(\mathrm{t}$ test) show that Institutional Ownership, Managerial Ownership, Individual Ownership, Foreign Ownership and Board of Commissionairs partially influence Earnings Management. This means that the existence of Institutional Ownership, Managerial Ownership, Individual Ownership, Foreign Ownership and Commisionaires Committee variables that affect Earnings Management will cause directors to be reluctant to carry out Earnings Management. Meanwhile, State of Ownership, Family Ownership, Public Ownership, Public Accountant, Audit Committee and Board of Directors have no effect on Earnings Management. This means that the involvement of these six variables or not, Earnings Management will still be carried out by the directors, even with the establishment of the Board of Directors, they will still carry out Earnings Management for the individual interests of the Directors.

According to (Muliasari \& Dianati, 2014) research on Earnings Management in Islamic business ethics is in the form of fraud that is intentionally carried out or is fraudulent in nature to achieve certain interests that are not for the benefit of the people or society, and this is not allowed. So that in Islamic Banking, Earnings Management should not be carried out for the interests of the board of directors or the interests of certain groups. In other words, Islamic Business Ethics expressly refuses.

However, the researcher is optimistic and believes that the merger of three large state Islamic banks will make the Islamic banking sector have the ability to advance and the world of Islamic banking will be stronger because the three large Islamic banks have improved themselves and delivered open information. So that other Islamic banking sectors, especially the private sector, will slowly take part in improving, besides that the state needs to protect and carry out strict supervision of directors not to carry out fraudulent Earnings Management. 
Effect of Simultaneous Independent Variables on Earnings Management ( $Y$ )

The test results in Table 6 obtained Fcount of 0.663470 with a significance value of 0.000000 . The Ftable value is 3.74 , therefore, it is known that the calculated $\mathrm{F}$ value $>\mathrm{F}$ table $(16.96928>3.74)$ and the significance value is 0.000000 (less than 0.05). It can be concluded that Institutional Ownership $\left(\mathrm{X}_{1}\right)$, Managerial Ownership $\left(\mathrm{X}_{2}\right)$, Individual Ownership $\left(\mathrm{X}_{3}\right)$, Foreign Ownership $\left(\mathrm{X}_{4}\right)$, State of Ownership $\left(\mathrm{X}_{5}\right)$, Family Ownership $\left(\mathrm{X}_{6}\right)$, Public Ownership $\left(\mathrm{X}_{7}\right)$, Public Accountant $\left(\mathrm{X}_{8}\right)$, Board of Commissionairs $\left(\mathrm{X}_{9}\right)$, Audit Committee $\left(\mathrm{X}_{10}\right)$ and Board of Directors $\left(\mathrm{X}_{11}\right)$ simultaneously have a significant effect on Earnings Management (Y). The value of $\mathrm{R}$ square is 0.804261 and adjusted square 0.77084 states that Institutional Ownership, Managerial Ownership, Individual Ownership, Foreign Ownership, State of Ownership, Family Ownership, Public Ownership, Board of Commissioners, Public Accountant, Audit Committee and Board of Directors are able to explain Earnings Management of $77.08 \%$. Earnings Management is in the form of fraud which can be reduced if its influence is not supported by Institutional Ownership, Managerial Ownership, Individual Ownership, Foreign Ownership, State of Ownership, Family
Ownership, Public Ownership, Board of Commissioners, Public Accountant, Audit Committee and Board of Directors. Accounting is the language of business and the heart of the company which is manifested in the form of clear and honest numbers so that it is very useful for the benefit of mankind. So that this form of cheating in terms of Islamic business ethics is not allowed because it will have an impact on the destruction of the company. This has been taught in the Qur'an and Hadith. Submission of clear information is very necessary in transactions in Islamic banking.

This is in line with research according to (Marzuqi \& Latif 2010) which states that Earnings Management is the behavior of a manager or director towards Earnings Management which is done by manipulating earnings figures on paper and this is not in accordance with what is guided by Islamic teachings. (Marzuqi \& Latif 2010) states that Islam views managers or directors and accountants as having honest character, keeping the trust and being honest in financial reporting to users. Honesty will avoid things that can harm one party. This is in line with the thoughts of the researcher that Earnings Management in the form of fraud involving and harming parties is strictly prohibited. Earnings 
Management which is for the common interest, for example during a pandemic or disease outbreak or the people's economy is in recession so that the government improves the profit-sharing margin set by the Financial Services Authority. In calculating taxes in accordance with Financial Accounting Standards it is permissible because taxes are for the benefit of the state and society. Tax revenue will bechanneled again for the benefit of mankind such as social costs for the welfare of mankind, repair and construction of roads for the benefit of society. This is allowed.

\section{CONCLUSION, IMPLICATION AND LIMITATION}

The results of the partial test $(\mathrm{t}$ test) state that Institutional Ownership, Managerial Ownership, Individual Ownership, Foreign Ownership and Board of Commissioners have an effect on Earnings Management. This means that the variables of Institutional Ownership, Managerial Ownership, Individual Ownership, Foreign Ownership and the Commissioners Committee have an effect on Earnings Management which causes directors not to carry out Earnings Management.

This study combines eleven variables and if they have an effect, it will cause Earnings Management by directors of a fraudulent nature to be further reduced or the directors will be reluctant to carry out earnings management. The more variables that affect the more reluctant the directors to do Earnings Management. So that the survival of the company is maintained.

\section{Conducting}

Earnings Management for individual interests or the interests of certain groups should not be carried out by the directors because it will interfere with the continuity or going concern of the company. The company's operations cannot be separated from ethics and business. The language of business in the business world is accounting. In accounting can not be separated from unqualified financial reporting.

It is hoped that further research can be carried out in the form of combining research that includes other variables such as ethics in business by looking for data taken from experiments and questionnaires from people or companies that have business links with Islamic banking being studied

\section{REFERENCES}

Achmad, T. (2008). Concentrated Family Ownership Structures Weakening Corporate Governance: A Developing Country Story, The Case of Indonesia Companies. Jurnal Manajemen Akuntansi \& Sistem Informasi, 8(2), 118-134. 
Adrian, S. (2012). Good Corporate Governance. Sinar Grafika.

Arief, Tegar (2019, April 23) Terjadi 4 Internal Fraud di BJB Syariah Selama 2018. Diakses pada 25 April 2021, dari https:/ finansial.bisnis.com/read/ 20190423/90/914480/terjadi-4internal-fraud-di-bjb-syariahselama-2018.

Aryani, W., \& Raharja, S. (2011). Mekanisme Corporate Governance Dan Manajemen Laba Melalui Manipulasi Aktivitas Riil.

Azib, Harahap, D. A., \& Amanah, D. (2020). The manufacturing company performance: The effect of internationalization and funding decision. International Journal of Research in Business \& Social Science, 9(4), 220-227.

Azim, M. I. (2012). Corporate Governance Mechanisms and Their Impact on Company Performance: A Structural Equation Model Analysis. Australian Journal of Management, 37(3), 481-505.

Boediono, G. S. (2005). Kualitas Laba: Studi Pengaruh Mekanisme Corporate Governance dan Dampak Manajemen Laba dengan Menggunakan Analisis Jalur. Simposium Nasional Akuntansi VIII.

Ching-Tang Hsieh Hao-Chen Huang Wei-Long Lee , (2016),"Using transaction cost economics to explain open innovation in startups", Management Decision, Vol. 54 Iss $9 \mathrm{pp}$.

Chung, K. H., \& Zhang, H. (2011). Corporate governance and institutional ownership. Journal of Financial and Quantitative Analysis, 46(1), 247-273.
Coase R.H. (1937), "The nature of the firm", Economica, Vol. 4 No. 16, pp. 386-405.

Deng, Y., Morck, R., Wu, J., \& Yeung, B. (2015). China's pseudomonetary policy. Review of Finance, 19(1), 55-93.

Douma, S., George, R., \& Kabir, R. (2011). Foreign and Domestic Ownership, Business Groups and Firm Performance: Evidence from a Large Emerging Market. SSRN Electronic Journal.

Effendi, S., \& Daljono. (2013). Pengaruh Corporate Governance Dan Kualitas Auditor Terhadap Manajemen Laba. Diponegoro Journal of Accounting, July, 811824.

Ermiati, C., Amanah, D., Agustini, F., Putri, C. R. N., \& Harahap, D. A. (2020). Kinerja Keuangan Bank Umum Syariah Di Indonesia Periode 2016-2019. Jurnal Ilmiah Manajemen Dan Bisnis, 5(2), 110.

Ferdawati. (2010). Pengaruh Kepemilikan Mangerial dan Kepemilikan institusional Terhadap Managemen Laba Real. 4(1), 55-67.

Ghozali, I. (2018). Aplikasi Analisis Multivariate dengan Program IBM SPSS 25. Badan Penerbit Universitas Diponegoro.

Hartini, M. . (2017). State-Owned Enterprises: a Comparison Between the UK, Japan, and Malaysia. International Journal of Economics, Commerce and Management, 5(2), 114-130.

Holieff, Meygantara Faozal \& Prawira Fajarindra Belgiawan. (2018). Cost-Based Analysis of Conventional and Autonomous Mobile Services in Indonesia. 
ICMEM.

Iqbal, A. S. J. \& M. (2012). Analisis Perbandingan Kinerja Keuangan Perbankan Konvensional Dan Perbankan Syariah. Journal of Management: Small and Medium Enterprises (SMEs), 7(2), 337-359. https://doi.org/10.35508/jom.v1 $1 \mathrm{i} 1.2319$

Jussila, I., Tarkiainen, A., Sarstedt, M., \& Hair, J. F. (2015). Individual Psychological Ownership: Concepts, Evidence, and Implications for Research in Marketing. The Journal of Marketing Theory and Practice, 23(2), 121-139.

Kolsi, M. C., \& Grassa, R. (2017). Did corporate governance mechanisms aff ect earnings

management? Further evidence from GCC Islamic banks. International Journal of Islamic and Middle Eastern Finance and Management, 10(1), 2-23. https://doi.org/10.1108/IMEFM -07-2015-0076.

Latif, A. Y. M. \& A. B. (2010). Earnings Management Dalam Tinjauan Etika bisnis Islam. Jurnal Dinamika Ekonomi Dan Bisnis, 7(2), 1-22.

Lidyah, R. (2018). Islamic Corporate Governance, Islamicityfinancial Performance Index And Fraudat Islamic Bank. Jurnal Akuntansi, 22(3), 437-453.

Mersni, H., \& Ben Othman, H. (2016). The impact of corporate governance mechanisms on earnings management in Islamic banks in the Middle East region. Journal of

Islamic Accounting and Business Research, 7(4), 318-348. https: //doi.org/10.1108/

JIABR-11-2014-0039.
Michael R. Braun Scott F. Latham, (2007),"The governance of going private transactions", Management Decision, Vol. 45 Iss 5 pp. $866-882$.

Mousa, G. A., \& Desoky, A. (2019). The effect of dividend payments and firm's attributes on earnings quality: Empirical evidence from Egypt. Investment Management and Financial Innovations, 16(1), 14-29.

Muliasari, I., \& Dianati, D. (2014). Manajemen Laba dalam Sudut Pandang Etika Bisnis Islam. Jurnal Akuntansi Dan Keuangan Islam, 2(2), 157-182. https://doi.org/10.35836/jakis.v $2 \mathrm{i} 2.47$

Nicholson, Gavin \& Newton, C. (2010). The Role of the Board of Directors: Perceptions of Managerial Elites. Journal of Management and Organization, 16(2), 201-218.

Panda, B., \& Leepsa, N. . (2017). Agency theory: Review of Theory and Evidence on Problems and Perspectives. Indian Journal of Corporate Governance, 10(1), 7495.

Pearce, J. A., \& Zahra, S. A. (2007). Board composition from a strategic contingency perspective. Journal of Management Studies, 29(4), 411-438.

Pratiwi, Y. D., \& Meiranto, W. (2013). Pengaruh Penerapan Corporate Governance Terhadap Earnings Management Melalui Manipulasi Aktivitas Riil. Diponegoro Journal of Accounting, July, 867-871. 
Pujiningsih, A. I. (2011). Pengaruh Struktur Kepemilikan, Ukuran Perusahaan, Praktik Corporate Governance Dan Kompensasi Bonus Terhadap Manajemen Laba.
Ramachandran, J., Ngete, Z.A., Subramanian, R., \& Sambasivan, M. (2015). Does corporate governance influence earnings management? : Evidence from Singapore. The Journal of Developing Areas, 49(3), 263-274. https://doi.org/10.1353/jda.2015 .0169 . 